\title{
PENGARUH SUSU SKIM TERHADAP PENAMPILAN AYAM PETELUR
} JANTAN

\author{
Sulis Dianto $^{1),}$ dan Agustina Widyasworo Kunharjati ${ }^{2)}$ \\ ${ }^{1)}$ Mahasiswa Program Studi Ilmu Ternak Fakultas Peternakan \\ ${ }^{2)}$ Dosen Program Studi Ilmu Ternak Fakultas Peternakan \\ Universitas Islam Balitar \\ Jl. Majapahit No. 04 Kota Blitar
}

\begin{abstract}
One effort to improve the efficiency and effectiveness of the production of roaster of broiler, can be done by improving the quality of feed is one of the skim milk dairy products in the solid form with the potential to supply poultry feed. Skim milk contains all the nutrients of milk except fat and vitamins that are fat soluble. This study aims to determine the effect of skim milk on the growth of roaster of broiler. Research using experimental design completely randomized design (completely randomized design). The material used in this study were male laying hens as much as 60 head aged 30 days to harvest at the age of 58 days. Skim milk from KUD Cement. Feed used is BR 1 of PT. Cargill Indonesia. Stage enclosure for maintenance, measuring $2 \mathrm{~m} \times 1.5 \mathrm{~m}$ and is divided into 12 plots and each 1 plot size is $50 \mathrm{~cm} \times 50 \mathrm{~cm}$, each plot contained 5 chickens. The variables in this study were feed consumption, body weight gain and feed conversion ratio (FCR). Research results obtained three conclusions that the addition of skim milk significant effect $(\mathrm{P}>0.01)$ on increasing body weight roaster of broiler P1 $=120 \mathrm{~g} /$ head $/$ week. The addition of milk skin significant $(\mathrm{P}>0.01)$ in penurunkan figures feed convertion ratio $(\mathrm{FCR})$ roaster of broiler by $\mathrm{P} 1=1.90$. Treatment addition of $7.5 \%$ skim milk gives the best effect on improving body weight gain and feed convertion ratio (FCR) of roaster of broiler. Based on the results of the study suggested, adding skim milk can be used up to the level of $7.5 \%$ in the diet of roaster of broiler, but need considering economic efficiency.
\end{abstract}

Keywords: Skim milk, appearance, roaster of broiler.

\section{PENDAHULUAN}

Ayam petelur jantan merupakan limbah dari pembibitan ayam ras petelur.

Wafiatiningsih dan Bariroh (2010) menyatakan akhir-akhir ini mulai banyak peternak unggas memelihara ayam petelur jantan yang merupakan hasil ikutan penetasan ayam petelur komersial impor dengan tujuan untuk menghasilkan daging. 
Keberhasilan usaha beternak ayam pedaging ditentukan oleh empat faktor dasar yang sangat berperan antara lain adalah pemilihan bibit unggul (breeding), kualitas dan kuantitas pakan (feeding), tata laksana pemeliharaan (management) serta pengendalian penyakit (Putri, 2011). Apabila dilihat dari total biaya produksi dalam usaha peternakan, kontribusi pakan adalah yang paling tinggi yaitu sekitar $75 \%$ nya. Salah satu upaya untuk memperbaiki efisiensi dan efektifitas produksi ayam petelur jantan, dapat dilakukan dengan memperbaiki kualitas pakan. Pemberian susu afkir pada persentase $10 \%$ dapat meningkatkan konsumsi pakan, meningkatkan pertambahan bobot badan serta menurunkan angka konversi pakan ayam pedaging jantan (Nur dkk, 2014).

Susu skim merupakan salah satu produk susu berbentuk padat yang potensial untuk penyediaan pakan ternak unggas. Susu skim mengandung semua zat makanan dari susu kecuali lemak dan vitamin-vitamin yang larut dalam lemak. Nutrisi susu skim terdiri dari protein $35-37 \%$, lemak $8 \%$, lactosa $49 \%-52 \%$, air 3\%, dan abu $7.5 \%-8 \%$ (Soeparno 1998 disitasi oleh Setya (2012).

\section{BAHAN DAN METODE}

Penelitian ini dilaksanakan pada bulan Agustus sampai September 2015 selama 28 hari yang berlokasi di Desa Gadungan, Kecamatan Gandusari, Kabupaten Blitar.

\section{Materi Penelitian}

Materi yang digunakan pada penelitian ini adalah ayam petelur jantan sebanyak 60 ekor yang berumur 30 hari hingga panen pada umur 58 hari. Susu skim dari KUD Semen. Pakan yang digunakan adalah BR 1 dari PT. Cargill Indonesia dengan komposisi disajikan pada Tabel 1.

Peralatan yang digunakan dalam penelitian antara lain:

a) Kandang panggung untuk pemeliharaan, berukuran $2 \mathrm{~m} \times 1.5 \mathrm{~m}$ yang terbagi menjadi 12 petak dan ukuran tiap 1 petak adalah $50 \mathrm{~cm} \times 50 \mathrm{~cm}$, tiap petak berisi 5 ekor ayam.

b) Tempat makan dan minum, setiap petaknya diberi 1 tempat makan dan 1 tempat minum.

c) Sekat pembatas, tirai luar dan tirai dalam.

d) 6 lampu 18 Watt buat penerangan

e) Timbangan digital untuk menimbang susu skim, sisa pakan dan timbangan corong buat menimbang ayam

f) Tiga ember dengan kapasitas 5 liter, untuk mencampur pakan komersial dengan susu skim.

g) Kamera digital digunakan dokumentasi .

\section{Metode Penelitian}

Ayam berumur 30 hari dilakukan pembagian kelompok secara acak yang dibagi menjadi 12 petak. Setiap petak terdiri dari 5 ekor ayam. Penelitian menggunakan metode eksperimen rancangan acak lengkap (completely randomized design) dengan 4 
perlakuan dan 3 ulangan. Adapun perlakuan yang diberikan dapat diuraikan seperti sebagai berikut:

P0 : pakan komersial tanpa penambahan susu skim (kontrol),

$\mathrm{P} 1$ : pakan komersial $+7,5 \%$ susu skim,

$\mathrm{P} 2$ : pakan komersial $+10 \%$ susu skim,

$\mathrm{P} 3$ : pakan komersial $+12,5 \%$ susu skim,

\section{Pembuatan campuran pakan}

a) Pakan komersil di timbang sesuai dengan kebutuhan ayam petelur

b) Susu skim di timbang sesuai level pemberian

c) Setelah pakan komersil dan susu skim di timbang di lakukan pencampuran pakan komersil dan susu skim dengan ember 5 liter pada setiap perlakuan.

\section{Tahap Adaptasi}

Ayam datang umur 30 hari , terlebih dahulu ditimbang untuk mengetahui bobot awal ayam sebelum diberi perlakuan.Selanjutnya ayam di taruh dikandang yang sudah di petak-petak secara acak yaitu 3 ulangan 4 perlakuan, berikut skema tata letaknya. Ayam diberi pakan yang sudah diberi susu skim dengan takaran yang sudah ditentukan, pemberian air minum dengan sistem ad libitum Ayam diberi makan dan minum pada pukul 7 pagi , dan besoknya pada pukul pukul 6 pagi sisa pakan ditimbang begitu seterusnya setiap hari sampai ayam umur 58 hari. Setiap 7 hari dilakukan penimbangan pada ayam per petak, untuk mengetahui pertambahan bobotayam.

\section{HASIL DAN PEMBAHASAN}

\section{Konsumsi Pakan}

Hasil rata-rata konsumsi pakan selama penelitian yang mendapatkan penambahan susu skim secara lengkap disajikan pada tabel 2 .

Tabel 2 . Konsumsi Pakan Pada Ayam Petelur Jantan (g/ekor/hari)

\begin{tabular}{cc}
\hline Perlakuan & Konsumsi Pakan \\
\hline P0 & 36,33 \\
P1 & 37,33 \\
P2 & 38,00 \\
P3 & 38,00 \\
\hline
\end{tabular}

Berdasarkan analisis ragam menunjukkan bahwa penambahan susu skim tidak berbeda nyata $(\mathrm{P}>0,05)$ terhadap konsumsi pakan. Kecenderungan peningkatan konsumsi pakan yang diberi tambahan susu skim disebabkan penambahan susu skim lebih tinggi. Dari data tersebut menunjukkan bahwa susu skim dapat meningkatkan konsumsi pakan. Hal ini sesuai menurut (Nur, 2014) peningkatan konsumsi disebabkan susu skim memberikan bau dan rasa yang baik pada pakan sehingga ayam akan menyukai pakan yang diberi susu skim dan berdampak pada konsumsi pakan menjadi tinggi.

Kandungan protein pada pakan setiap perlakuan yaitu $\mathrm{P} 0=20 \%, \mathrm{P} 1=$ $21,05 \%, \mathrm{P} 2=21,36 \%$ dan $\mathrm{P} 3=21,61 \%$. Kandungan protein pada pakan tiap perlakuan 
lebih tinggi dari pada perlakuan kontrol. Semakin tinggi kandungan protein dalam pakan semakin tinggi pula konsumsi pakan yang di konsumsi. Hal ini sesuai dengan pendapat Tampubolon et al., (2012) bahwa asupan protein dipengaruhi oleh jumlah konsumsi ransum. Konsumsi ransum dipengaruhi oleh kandungan energi yang terdapat didalamnya.

Peningkatan konsumsi pakan pada perlakuan dimungkinkan dengan penambahan susu skim jumlah energi dalam ransum menjadi turun, sehingga konsumsi ayam menjadi meningkat. Sesuai menurut Kartasudjana dan Suprijatna (2006) ayam mengkonsumsi ransum untuk memenuhi kebutuhan energinya, sebelum kebutuhan energinya terpenuhi ayam akan terus makan. Jika ayam diberi makan dengan kandungan energi rendah maka ayam akan makan lebih banyak. Jumlah pakan yang dikonsumsi juga dipengaruhi faktor besar hewan, keaktifan, temperatur, lingkungan dan tingkat energi dalam pakan.

\section{Pertambahan Bobot Badan}

Hasil rata-rata penimbangan bobot badan selama penelitian secara lengkap disajikan pada tabel 3 .

Tabel 3 . Peningkatan Bobot Badan Ayam Petelur Jantan (g/ekor/minggu)

\begin{tabular}{cc}
\hline Perlakuan & Pertambahan Bobot Badan \\
\hline P0 & $88,33^{\mathrm{a}}$ \\
P1 & $120,00^{\mathrm{b}}$ \\
P2 & $111,67^{\mathrm{b}}$ \\
P3 & $101,67^{\mathrm{b}}$ \\
\hline
\end{tabular}

Keterangan : a-b superskrip yang berbeda dalam kolom yang sama menunjukkan perbedaan yang sangat nyata antar perlakuan

Berdasarkan analisis ragam menunjukkan bahwa penembahan susu skim berbeda sangat nyata $(\mathrm{P}>0,01)$ terhadap pertambahan bobot badan. Peningkatan pertambahan bobot badan pada $\mathrm{P} 1$ diduka nutrisi dalam ransum diserap dengan baik oleh alat pencernaan ayam petelur jantan. Asupan nutrisi yang masuk ke dalam tubuh cukup yang berdampak pada peningkatan berat badan bila dibandingkan dengan P0. Kandungan energi dan nutrisi yang meliputi protein, karbohidrat, lemak, serat kasar, kalsium, bahan kering, BETN serta energi metabolisme yang memiliki sedikit perbedaan juga dapat berpengaruh pada pertambahan berat badan( Nur et. all, 2014). Menurunnya pertambahan berat badan pada perlakuan P2 diduga karena kandungan laktosa dalam susu skim tidak dapat dicerna oleh ayam petelur jantan. Jumlah laktosa yang menyebabkan gejala bervariasi, tergantung pada jumlah laktosa yang dikonsumsi, derajat defisiensi laktosa, dan bentuk makanan yang dikonsumsi (Heyman, 2006).

\section{Feed Conversion Ratio (FCR)}


Hasil rata-rata feed conversion ratio ayam petelur jantan yang mendapatkan penambahan susu skim secara lengkap disajikan pada tabel 4.

Tabel 4 . Feed Conversion Ratio Pakan Ayam Petelur Jantan

\begin{tabular}{cc}
\hline Perlakuan & Pertambahan Bobot Badan \\
\hline P0 & $2,53^{\mathrm{b}}$ \\
P1 & $1,90^{\mathrm{a}}$ \\
P2 & $2,10^{\mathrm{a}}$ \\
P3 & $2,43^{\mathrm{b}}$
\end{tabular}

Keterangan : a-b superskrip yang berbeda dalam kolom yang sama menunjukkan perbedaan yang sangat nyata antar perlakuan

Hasil analisis sidik ragam menunjukkan bahwa level penambahan susu skim pada pakan berpengaruh nyata $(\mathrm{P}>0,01)$ terhadap feed conversion ratio ayam petelur jantan pada perlakuan P1 dengan rataan 1,90 dibandingkan dengan perlakuan kontrol $\mathrm{P} 0$.

Feed conversion ratio (FCR) pakan ayam petelur jantan didapatkan dari data konsumsi pakan dan pertambahan berat badan, yaitu konsumsi pakan ayam petelur jantan selama penelitian dibagi dengan pertambahan berat badan selama penelitian. Pada pakan perlakuan P1, P2 dan P3 yang ditambah susu skim menunjukkan perbedaan yang nyata terhadap kontrol, hal ini disebabkan susu skim mempunyai kandungan zat nutrisi mikro (vitamin, mineral dan asam amino) yang komplit, sehingga dapat menurunkan angka konversi pakan. Konversi pakan pada masing-masing perlakuan yang berbeda nyata menunjukkan bahwa susu skim dapat meningkatkan daya cerna ayam petelur jantan. Semakin kecil konversi pakan maka akan semakin menguntungkan karena semakin sedikit jumlah konsumsi untuk menghasilkan daging selama waktu penelitian (Nasution, 2009).

Peningkatan angka feed conversion ratio (FCR) pada $\mathrm{P} 2$ dan $\mathrm{P} 3$ diduga disebabkan karena ketidak mampuan tubuh untuk menyerap nutrisi pakan dengan baik. Dalam susu terdapat laktosa 49\%-52\%. Laktosa adalah gula susu dan hanya terdapat dalam susu (atau hasil-hasil dari susu). Zat tersebut terdiri dari satu molekul glukosa dan satu molekul galaktosa. Laktosa tidak dapat digunakan oleh ayam karena sekresi pencernaan ayam yang tidak mengandung enzim laktosa yang diperlukan untuk mencerna laktosa. 


\section{KESIMPULAN}

Berdasarkan penelitian dapat disimpulkan bahwa, penambahan susu skim memberikan pengaruh terbaik pada peningkatan bobot badan ayam pedaging jantan $\mathrm{P} 1=120 \mathrm{~g} / \mathrm{ekor} / \mathrm{minggu}$. Penambahan susu skim memberikan pengaruh terbaik untuk menurunkan angka feed convertion ratio (FCR) ayam petelur jantan sebesar $\mathrm{P} 1=1,90$. Perlakuan penambahan $7,5 \%$ susu skim memberikan pengaruh terbaik pada peningkatan bobot badan dan feed convertion ratio (FCR) ayam pedaging jantan

\section{DAFTAR PUSTAKA}

Adiguna Akbar. 2009. Evaluasi Nutrisi Ransum Ayam Broiler Di Cv Pandu Putra Mandiri Desa Cibolang Kecamatan Karang Tengah Kabupaten Sukabumi. Universitas Diponegoro. Semarang

Anonim. 2008. Pemeliharaan Ayam Petelur Jantan. Direktorat Pembinaan SMK. Asmarasari dan Suprijatna. 2008. Pengaruh Penggunaan Kunyit Dalam Ransum Universitas Diponegoro

Ahmad, A.W. 2011. Strategi Pengembangan Usaha Ayam Petelur Jantan Pada Ud. Mangestoni Putri Poultry Shop Di Desa Gadingsari Kecamatan Sanden Kabupaten Bantul. Institut Pertanian Bogor

Fadilah, R. 2004. Ayam Broiler Komersial. Agromedia Pustaka. Jakarta.

Gerken, M., D. Jaenecke and M. Kreuzer. 2003. Growth, behaviour and carcass characteristics of egg-type cockerels compared to male broiler. World's Poult. Sci. Vol. 59,March 2003.

Heyman MB. 2006. Lactose ntolerance in infants, children, and adolescent. Ped. J. $118,3,1279$.

Imam, F,I. 2009. Manjemen Pemeliharaan Ayam Petelur Di Peternakan Dony Farm. Kabupaten Magelang. Universitas Sebelas Maret. Surakarta

Irianto, A. 2011. Pengaruh Pemberian Yoghurt Susu Afkir yang Diperkaya Nata de Coco dalam Mengendalikan Kolesterol Darah Tikus Putih. Fakultas Biologi Universitas Jendral Soedirman. Purwokerto.

Katsir, I. 2003. Pentingnnya Suplementasi Ransum. Info Medion. Bandung. Nasution, E. Z. J. 2009. Pemanfaatan Isi Rumen yang Difermentasi Dengan Probiotik sebagai Substitrusi Bekatul terhadap Performan Ayam Pedaging. Skripsi Fakultas Kedokteran Hewan Universitas Airlangga. Surabaya. Nur, Hadi dan Wurlina. 2014. Pengaruh Pemberian Susu Afkir Terhadap Performanayam Pedaging Jantan. Universitas Airlangga. Surabaya.

Putri, I. 2011. Pemberian Tepung Limbah Tempe Fermentasi Sebagai Subtitusi Jagung Terhadap Konsumsi dan Efisiensi Pakan Ayam Pedaging Jantan. Skripsi Fakultas Kedokteran Hewan Universitas Airlangga. Surabaya Rasyaf. 2004. Beternak Ayam Pedaging. Penebar Swadaya, Jakart Rifqi Ata. 2008. Pengaruh Pemberian Feed Additive "Ri.1" Dan Jenis Pakan

Yang Berbeda Terhadap Penampilan Ayam Broiler. Institut Pertanian Bogor. Bandung. 
Setya, A, W. 2012. Teknologi pengolahan susu. Universitas sebelas maret. Surakarta.

Steel, R. G.D. dan J.H. Torrie. 1991. Prinsip dan Prosedur Statistika : Suatu Pendekatan Biometrik. Terjemahan : M.Syah. PT. Gramedia Pustaka Utama, Jakarta.

Sufi Anggi HN. 2008. Performa Ayam Broiler Yang Mendapat Ransum Bersuplemen Cr Organik Dan Dipelihara Pada Kepadatan Kandang Yang Berbeda . Institut Pertanian Bogor. Bandung

Suprijatna, E., U. Atmomarsono., dan R, Kartasudjana. 2005. Ilmu Dasar Ternak Unggas. Penebar Swadaya. Jakarta.

Sutrisno, K. 2009. Teknologi Pengolahan Susu. E-book

Tamalluddin, F. 2014. Panduan Lengkap Ayam Broiler. Jakarta : Penebar Swadaya Tampubolon. Bintang, P.P. 2012. Pengaruh Imbangan Energi dan Protein Ransum terhadap Energi Metabolis dan Retensi Nitrogen Ayam Broiler. Jurnal Fakultas Peternakan Universitas Padjadjaran, Bandung

Wafiatiningsih dan N.R. Bariroh. 2010. Pengaruh Penggunaan Tepung Kencur Sebagai Feed Suplemen Terhadap Karkas Ayam Petelur Jantan. Samarinda. Wahju, J. 2004. Ilmu Nutrisi Unggas. Gadjah Mada University Press. 